\title{
MARKETING STRATEGY AND BUILDING BRAND VALUE ON THE HUNGARIAN MARKET
}

\author{
Zoltán Zéman $^{1, \mathrm{a},{ }^{*} \text { and Alexandru Bogdan }}{ }^{2, \mathrm{~b}}$ \\ ${ }^{1}$ Faculty of Economics and Social Sciences, Institutes of Business Sciences, Szent István Unviversity, \\ H-2100, Gödöllő, Páter Károly utca 1, Hungary \\ ${ }^{2}$ The Economics I Doctoral School, Bucharest University of Economic Studies, 6 Piata Romana, $1^{\text {st }}$ \\ district, Bucharest, 010374 Romania \\ azeman.zoltan@gtk.szie.hu, bodgan.alex25@gmail.com \\ *Corresponding author
}

Cite as: ZÉMAN, Z., BOGDAN, A. (2019). Marketing strategy and building brand value on the Hungarian market, Ekonomicko-manazerske spektrum, 13(2), 1-9.

Available at: dx.doi.org/10.26552/ems.2019.2.1-9

\begin{abstract}
A fundamental feature of the continuous change, which is mainly marked by the globalization, as an accompanying feature of the changing needs and wishes of millions of customers, has created a strategic marketing position. The constant pressure of competition, which in developed countries has gone through to hyper-competition, forces companies to adapt flexibly to the situation. Technological and technological progress, especially in the field of information networks, is changing our world very quickly. Businesses started to focus on supporting the brand, but also a more balanced perspective on the managers' attention than the creators and builders of a successful brand. So, more attention is paid to internal brand building, as its successful future is attributed to the role of creators - employees. This research paper aim is to propose an optimal marketing strategy for building a successful brand and managing its value in a selected company that is starting to enter the Hungarian market. To find out information, we conducted a controlled interview with the business owner, and at the same time, we analysed the market by exploratory questions. We verified the hypotheses to support our design solution for the entry of a new company into the already established competitive market.
\end{abstract}

Keywords: brand building, brand management, strategic marketing, brand value, brand management

JEL Classification: D47, L11, O32

\section{Introduction}

Based on the research and evaluation of enterprises was found that in most successful companies, it is commonplace to use production and commercial techniques and modern technologies. Their results are based on proper work with the market, its ongoing analysis, and adaptation of marketing strategies. (Kim and Ko, 2012)

However, this will no longer be sufficient to maintain long-term performance in the modern era of rapid information and communication technology developments, in accordance with Lähtinen et al. (2014). Building a strong brand comes to the forefront, which does not only mean creating a beautiful and duly expensive logo, nor is it enough to launch a winning image campaign. This is a much more complicated process. Before design begins, a company should make it clear who it is, what brings customers to its and what it differs from the competition. (Eren-Erdogmus et al., 2018) 
We want to point out that even today, in the age of the Internet and the individual demands of diverse consumers, it is essential to build a strong brand and promote the image of society. From our point of view, branding is more important than ever and is a necessary investment in the future of the company.

The issue of branding and its building is relatively topical and is currently being addressed by many authors. Considerations and opinions come together and differ depending on different industry perspectives under investigation and, last but not least, on the industry nature. In the next section, we offer a brief overview of the authors who have worked on the topic or are still working on it. They are authors of publications from all over the world and authors of research articles published in the reputable database of Web of Science.

\subsection{Literature review}

Opinions on the importance of building a brand differ widely. On the one hand, there are ideas that these are compelling marketing agency methods designed to raise money from their customers. Another party agrees that brand building today is subject to the necessary investment in the future of the company.

By examining luxury brands (Stokburger-Sauer and Teichmann, 2013) that were in the process of building, encourage businesses to apply a top-down process. For companies in the position of strong brands, it is necessary to focus attention on the company. Successful brands benefit mainly from experienced managers. According to Brodie et al. (2013), these are merchants and sales agents whose sales skills are essential for businesses with strong brands.

Nowadays, people search for products with a brand that identifies them and represents their lifestyle. This view is taken by Gallarza and Saura (2006) and Zhang (2020) and further that brands should be built for specific customer needs. With as many emotional relationships between the brand and consumers as possible, their loyalty to the business and the business success itself will increase. The "normal" brand becomes a "brand loyalty," according to Laroche (2012), just as the company focuses on the positive emotions that arise at the customer and applies them to their products. Emotions work in favour of the brand, which should be conditional on fair value. Companies are already aware that their unique functional features of the brand are not difficult to understand because of the competition that can either overcome these features, whether they mimic them or not. As a result, according to Park et al. (2010) and Nadanyiova et al. (2019), companies focus on the process of obtaining recognition of their brand's specific emotional values.

The basic overview and stages of the marketing process in the selection and creation of strategies describe Ashley and Tuten (2015). Positioning is also part of the theme, as a critical element of marketing strategy that plays the role of brand building to make the brand take a different stance or leave a distinct impression on the customer's mind, as opposed to competition. Authors Gajo (2019), Murray et al. (2019) and Stahl et al. (2012) describe "positioning" as a revolutionary approach to create a "position" in the minds of potential customers. This position also reflects the company's strengths and weaknesses as well as its competitors. To attract business, it has to be differentiated and come up with something new that awakens the customer's curiosity. Huang (2019) speaks of the brand as a simple, clear-cut idea with a clear business strategy that effectively tells consumers what its differences are and why it deserves attention. To achieve a strong brand, the business must establish an exciting and straightforward idea with which the customer can quickly identify.

The value of the brand in the process of choosing a shopping place was discussed in more detail by Chaudhuri et al. (2001), which based on dependence - if the satisfaction rate increases, the perceived value of the brand and income increase at the same time. It also outlines the 
likelihood of choosing a point of purchase concerning brand perception and the impact of competing sellers.

A similar investigation made Xiong et al. (2017), who, using empirical analysis, identified four factors (quality, product, service, and social attributes) for the brand and ranked quality as the most crucial factor. On the other hand, Sweeney at al. (2001) based on their investigations, point to the fact that they increase brand value through consumer utility.

Authors Brodie et al. (2013), Kandampully et al. (2015) and Lähtinen et al. (2014) dealt with twenty-two unmistakable brand laws to create a world-class brand product or service and excel in today's crowded market. The authors mentioned above have attempted to study the Internet environment thoroughly and share their radical effective marketing strategies in the form of eleven immutable Internet branding laws.

Chaudhuri (2001) is an author who uses real brand-building examples (Saturn, Kodak, General Electric, McDonald's) in his works to demonstrate the creation and management of these strong brands. Srivastava et al. (1998) point to innovation, intuition, and risk. He explains how businesses can use design to create a unique brand message that connects buyers with a product. (Olah et al., 2019a, Olah et al., 2019b) The nature of the creative process leads to unusual solutions that attract people to the brand. Later in 2010, he focused on humanizing the branding process, creating a secure emotional connection that people have with brands. In one of his books, he emphasizes the need to move from a brand based on statistics and data to a visually convincing form of communication that fosters creativity and innovation. A revolutionary approach to brand marketing attributes Schmitt, which, through brands providing sensory, productive, and creative associations, highlights the ability of managers to create a holistic experience for their customers.

The question is, what makes things accessible, or why people talk about certain products more than others, or why online content becomes viral. See-To et al. (2014) tried to find answers to these questions. It proposes a set of specific, responsive techniques to help disseminate information that people will subsequently share.

The future of brands in today's global world and the problems businesses face today is explained by Gajo (2019), who also criticizes the erroneous actions of the companies that fail to build and lead brands effectively.

According to Park et al. (2010), we can characterize the brand as a "promise that connects a product or service with a consumer. Whether it is words, visuals or emotions, or any combination of these, brands are mental associations that emerge when you think or hear about a particular car or camera, watch, drink, organization, or even a country". It is clear from Adamson's understanding of the brand that the consumer automatically attributes, based on his observations, experience, and knowledge, to the particular product or service, the brand names that offer the goods or service.

Strategic marketing is based on the concepts of segmentation, target focus, and market positioning strategy. After choosing the appropriate value for the market, an enterprise can then define a product for which it sets a price and ultimately has to produce it and finally distribute it. Product and service development, pricing, and distribution can be ranked in the market value market. The last part of the process is called Value Tracking, which consists of the sales force, sales promotion, and advertising.

By building trade and growing customer base, increasing corporate value has a positive impact on economic development. (Almasi et al., 2019)

The business must make necessary individual decisions in the case of strategic and tactical marketing (Figure 1). 
Figure 1: Strategic and tactical balance of marketing

\begin{tabular}{|c|c|c|c|}
\hline \multirow{4}{*}{$\begin{array}{l}\text { Strategic } \\
\text { marketing } \\
\text { decisions }\end{array}$} & $\begin{array}{l}\text { Who to consider as an ideal } \\
\text { customer? }\end{array}$ & \multirow{4}{*}{$\begin{array}{c}\text { Tactical } \\
\text { marketing } \\
\text { decisions }\end{array}$} & $\begin{array}{l}\text { Selection of a specific product } \\
\text { to be offered }\end{array}$ \\
\hline & $\begin{array}{l}\text { What value to offer to this } \\
\text { customer? }\end{array}$ & & $\begin{array}{l}\text { What will the price of this } \\
\text { product offer? }\end{array}$ \\
\hline & $\begin{array}{l}\text { How to ensure customer } \\
\text { satisfaction? }\end{array}$ & & $\begin{array}{l}\text { Where, how and when will we } \\
\text { promote the product? }\end{array}$ \\
\hline & $\begin{array}{l}\text { How to maintain a } \\
\text { competitive position? }\end{array}$ & & $\begin{array}{l}\text { Where, how and when will we } \\
\text { be available to our customers? }\end{array}$ \\
\hline
\end{tabular}

Source: Ashley, C. \& Tuten, T. (2015). Creative strategies in social media marketing: An exploratory study of branded social content and consumer engagement. Psychology \& Marketing, 32(1), 15-27.

\section{Methodology}

The subjective opinion of the brand and the person purchasing preferences of furniture customers are an essential information basis for the creation of an effective marketing strategy with an emphasis on determining the positioning and values of the brand at its start.

One of the ways we got to the necessary information is through inquiry. Using the survey, we wanted to find out the opinions of customers on the brand in connection with furniture in general, their relation to branded products. Also, we tried to investigate what extent brand values influence their choice of a particular brand and emotions they feel in connection with the purchase of designer furniture.

Validation hypotheses are a useful tool for determining causality between individual results. By selecting the appropriate pair of questions to resolve the dependencies between them, we can improve the quality of the information base to create a branding marketing strategy.

According to conventional methods of optimal determination of the number of respondents, e.g., using Simple Calculator, we would need approximately 380 respondents. Given that this is a survey conducted for marketing purposes, 100 respondents will be sufficient as a relevant number of results. A total of 128 respondents participated in the questionnaire survey, of which $44.53 \%$ are women, and $55.47 \%$ are men. Of all the 108 people involved, the questionnaire completed electronically and 20 during the personal meeting.

\section{Results}

Our research paper aims to propose an optimal marketing strategy for building and managing the value of a brand entering the Hungarian market. Therefore, we decided to investigate and subsequently optimize the marketing strategy of the selected Hungarian company, which decided to launch in 2018 its brand on the market. As a result, since its inception, the company has been offering its products exclusively in Western European markets through business intermediaries who distributed products of the company on European markets under their trademarks.

\section{a. Segmentation}

The selected Hungarian company is not a brand designed for everyone. It has a specific position in the market and addresses a particular customer segment. In this step, we will try to 
properly break down customers into groups of people with common characteristics and needs. The estimated specification of customer groups is given in Table 1.

Table 1: Market segmentation of selected Hungarian furniture company

\begin{tabular}{l|l|l}
\hline Approaches & - & Include \\
\hline \multirow{5}{*}{ Demographic } & Gender & man and woman \\
& Age & from 21 years \\
& Education & single, in relationship, engagement \\
& Free cash & Secondary, college, university, higher education \\
from 50 EUR per month
\end{tabular}

Source: Own processing

\section{b. Target groups of potentially most active customers}

In the process of identifying the most potential and the most attractive target group of customers of the Hungarian furniture brand before the proposed optimization, we based on the subjective opinion on the current most effective target group of customers, due to the unavailability of information about customers. Among the potentially influential target groups, we have included engaged couples, people in a relationship, and newlyweds' customers, where we expect the group's most significant purchasing potential with a $45 \%$ share. The second most potential group includes companies looking for furnishing office facilities. The second group was assigned a $30 \%$ share. The third group included families who are considering the possibility of buying and renovation of old furniture for new with a $15 \%$ share.

Any business that wants to succeed on the market with its product offerings and strives to differentiate itself from competitors in a way that impresses customers and makes the brand adapt quickly to the minds of customers. The possibilities to differentiate are increasingly limited to the growing trend of emerging brands. The customer is overwhelmed with innumerable information, and it is natural to ignore many of them.

A brand that wants to establish itself on the market with something new and different from its competitors must have a precisely structured idea, a defined vision, and a bright optimally defined identity to competing brands. It should also devote considerable attention to the analysis of its competitors and, last but not least, to its target customers and to determine its optimal positioning based on selected parameters. (Labrecque and Milne, 2012)

To determine the dependence between some of our responses, we decided to use hypothesis testing. Hypothesis no. 1 - testing the dependence between interest in a branded product and attending a furniture exhibition.

\section{Determination of hypotheses:}

Hypothesis $\mathrm{H} 0$ : there is no dependence between interest in a branded product and visiting a furniture exhibition. 
Hypothesis H1: there is a dependence between interest in a branded product and a visit to a furniture exhibition.

To verify the independence between the above characters, we perform the Pearson chisquare independence test. First of all, we have to choose the level of significance that we have selected in our case $\alpha=0.05$. In the next step, we calculate the theoretical frequencies. For all theoretical frequencies in our case, at least $80 \%$ must be $\mathrm{E}_{\mathrm{ij}} \geq 5$. Based on the results, we fulfil this condition of inequality. There is Table 2 related to the calculation of test criterion from hypothesis no. 1 . The resulting value is compared with the value from the table of critical values $\mathrm{x}^{2}$ of the distribution: $X \sim \chi \mathbf{2} ; \mathbf{P}(X \geq \chi \mathbf{2}(\alpha))=\alpha$.

Table 2: Calculation of test criterion from hypothesis no. 1

\begin{tabular}{l|lll|l}
\hline \multirow{2}{*}{$\begin{array}{l}\text { Interest in branded } \\
\text { product }\end{array}$} & \multicolumn{2}{|l|}{ Visiting furniture exhibitions } & \multirow{2}{*}{ Total } \\
\cline { 2 - 4 } & Yes & $\begin{array}{l}\text { No, but certainly in the } \\
\text { future }\end{array}$ & No & 8.3025 \\
\hline Yes & 4.1103 & 0.0114 & 3.9598 & 6.8792 \\
No & 3.5790 & 0.0095 & 3.2808 & $\mathbf{1 5 . 1 8 1 0}$ \\
Total & 7.8911 & 0.0212 & 7.2412 & $\mathbf{1 0}$ \\
\hline
\end{tabular}

Source: Own processing

\section{$15.1820>x^{2}{ }_{0.05}(1 * 2)$}

\section{$15.1810>5.9915$}

Inequality was confirmed, which means that we reject the null hypothesis $\mathrm{H} 0$ and accept the alternative hypothesis $\mathrm{H} 1$, which means that there is a statistically significant dependence between interest in a branded product and visiting furniture exhibitions. Concerning the confirmation of $\mathrm{H} 1$, we decided to measure the intensity of dependence utilizing the Cramer coefficient, which is one of the most used methods of measuring the strength of dependency among the measured features. The coefficient can take values $\langle 0,1\rangle$, where for a value between 0 - 0.3, we can talk about a weak dependence, 0.3 - 0.8 mean moderate dependence, and from 0.8 - 1, we can talk about strong dependence between monitored characters.

$$
\mathrm{V}=\sqrt{\frac{x^{2}}{n \cdot \min \{r-1, s-1\}}}=\sqrt{\frac{15,181}{128 \cdot \min \{1,2\}}}=\mathbf{0 . 3 4 4}
$$

Where:

$$
\begin{aligned}
& \mathrm{V}-\text { Cramer coefficient, } \\
& \mathrm{x}^{2} \text { - value of Chi - sq. }
\end{aligned}
$$

From the result of the coefficient, we can assume that it is a moderate dependence between interest in a branded product and a visit to a furniture exhibition.

Hypothesis no. 2 - testing the relationship between customer preference of a branded product and customer interest in the brand

\section{Determination of hypotheses}

Hypothesis H0: there is no dependence between customer preference of the branded product and customer interest in the brand. 
Hypothesis H1: there is a dependence between the customer's preference for the branded product and the customer's interest in the brand.

We chose the significance level $\alpha=0.05$, as we did in the first hypothesis. The verification of the independence between the features as mentioned above is carried out using the Pearson chi-square independence test. In the next step, we calculated the theoretical frequencies, and for all theoretical frequencies in our case, it must be that at least $80 \%$ must be Eij $\geq 5$. From the results, it was evident that we meet the condition of inequality.

In the next step, we created Table no. 3 for the calculation of the test criterion. The resulting value is compared with the value from the table of critical values $\mathrm{x} 2$ of the distribution: $\boldsymbol{X} \sim$ $\chi 2 ; \mathbf{P}(X \geq \chi \mathbf{2}(\alpha))=\alpha$.

Table 3: Calculation of test criterion from hypothesis no. 2

\begin{tabular}{|c|c|c|c|c|}
\hline \multirow[b]{2}{*}{$\begin{array}{l}\text { I prefer } \\
\text { branded } \\
\text { products }\end{array}$} & \multicolumn{3}{|l|}{ Brand interest } & \multirow[b]{2}{*}{ Total } \\
\hline & $\begin{array}{l}\text { Brand vision } \\
\text { and values }\end{array}$ & $\begin{array}{l}\text { At least basic } \\
\text { information }\end{array}$ & $\begin{array}{l}\text { I don't need to know any } \\
\text { info, only interested in } \\
\text { products }\end{array}$ & \\
\hline Yes & 7.5647 & 1.7961 & 8.1206 & 17.4815 \\
\hline No & 6.2670 & 1.4880 & 6.7279 & 14.4859 \\
\hline Total & 13.8328 & 3.2839 & 14.8489 & 31.9662 \\
\hline
\end{tabular}

Source: Own processing

$$
31.9662>x^{2} 0,05(1 * 2)
$$

\section{$31.9662>5.9915$}

The inequality has been confirmed, i.e., we reject the null hypothesis $\mathrm{H} 0$ and accept the alternative hypothesis $\mathrm{H} 1$, which means that there is a statistically significant dependence between customer preference of the brand product and customer interest in the brand.

Due to the validity of the hypothesis H1, we measure the intensity of dependence using the Cramer coefficient.

$$
\mathrm{V}=\sqrt{\frac{x^{2}}{n \cdot \min \{r-1, s-1\}}}=\sqrt{\frac{31.9663}{128 \cdot \min \{1,2\}}}=\mathbf{0 . 5 0}
$$

Where:

$$
\begin{aligned}
& \mathrm{V}-\text { Cramer coefficient, } \\
& \mathrm{x}^{2}-\text { value of } \mathrm{Chi}-\mathrm{sq} .
\end{aligned}
$$

From the result of the coefficient, we can state that this is a moderate dependence between customer preference of the branded product and customer interest in the brand.

\section{Discussion}

When we think about how a person can have a relationship with furniture that serves him or her and plays a role in his or her home, we can talk about different kinds of emotional ties. The brand's vision should briefly characterize a better condition than the current one in such a way as to evoke emotions of a specific character to the customer, representing an evolutionary approach to the aesthetics and functionality of the brand's products, emphasizing the specificity 
of brand values. The basis for effective differentiation of the Hungarian furniture brand from other brands operating in the furniture segment is the different determination of the brand values. The values of this company should be based on the essential vision of the brand and target customers. From the established image of the brand in conjunction with the benefits of the target market, we propose that Deep Elegance promote its brand under the following values of high product quality and functionality, reliability and trust, the integration of talent and art in one place. The results of our survey indicate that the company will draw attention to customer service. Up to $36 \%$ of respondents decide whether to buy or not to buy a product based on active customer service, and up to $88 \%$ say they use customer service. An adequate source of brand value can provide flexible and rapid communication of customer support with the customer.

\section{Conclusion}

We intended to draw attention, especially to the marketing strategy of building and managing brand value. Today, it is no longer enough to emphasize the name of a business but to focus on brand integrity and vision with a suitable organizational culture that delivers benefits from managers who are a living embodiment of the brand, enabling customers to achieve a trusted and expected experience. It is essential that team building team members continue to be able to assess, monitor, and compare the results competitively with the initially set plans to provide incentives for changes that could lead to the achievement of their goals.

By analysing the needs and purchasing preferences of Hungarian customers in conjunction with the analysis of selected competing brands operating on the Hungarian market, we found a wealth of information that constituted a substantial part of the information base for designing an optimal marketing strategy to build and manage brand value entering the Hungarian market. In today's modern times, customers most often use the Internet to search for furniture. Therefore, we designed the brand to apply effective PPC campaigns and SEO optimization to commonly used keywords when searching for furniture. If today's modern phenomenon is almost every occasion to use the Internet, we have found that customers who prefer branded furniture attend furniture exhibitions. As a result, we have proposed to the company to participate in furniture exhibitions.

\section{References}

Almasi, B.Z. \& Zeman, Z. (2019). Macroeconomic growth in business valuation. Economic Annals-XXI, 175, (12), $18-23$.

Ashley, C. \& Tuten, T. (2015). Creative strategies in social media marketing: An exploratory study of branded social content and consumer engagement. Psychology \& Marketing, 32(1), 15-27.

Brodie, R.J., Ilic, A., Juric, B. \& Hollebeek, L. (2013). Consumer engagement in a virtual brand community: An exploratory analysis. Journal of business research, 66(1), 105-114.

Eren-Erdogmus, I., Akgun, I. \& Arda, E. (2018). Drivers of successful luxury fashion brand extensions: Cases of complement and transfer extensions. Journal of Fashion Marketing and Management: An International Journal, 22(4), 476-493.

Gajo, V.M. (2019). Internal and external branding: A case study of Simpo furniture company. Co Publisher, (12), 110 .

Gallarza, M.G. \& Saura, I.G. (2006). Value dimensions, perceived value, satisfaction and loyalty: an investigation of university students' travel behavior. Tourism Management, 27(3), 437-452.

Huang, G. (2019). Variation matters: How to curb ad intrusiveness for native advertising on Facebook, Twitter, and Instagram. Internet Research, 26(6), 1469-1484.

Chaudhuri, A. \& Holbrook, M.B. (2001). The chain of effects from brand trust and brand affect to brand performance: The role of brand loyalty. Journal of marketing, 65(2), 81-93. 
Kandampully, J., Zhang, T. \& Bilgihan, A. (2015). Customer loyalty: A review and future directions with a special focus on the hospitality industry. International Journal of Contemporary Hospitality Management, 27(3), 379414.

Kim, A.J. \& Ko, E. (2012). Do social media marketing activities enhance customer equity? An empirical study of luxury fashion brand. Journal of Business research, 65(10), 1480-1486.

Labrecque, L.I. \& Milne, G.R. (2012). Exciting red and competent blue: the importance of color in marketing. Journal of the Academy of Marketing Science, 40(5), 711-727.

Laroche, M., Habibi, M.R., Richard, M.O. \& Sankaranarayanan, R. (2012). The effects of social media based brand communities on brand community markers, value creation practices, brand trust and brand loyalty. Computers in Human Behavior, 28(5), 1755-1767.

Lähtinen, K., Alina Samaniego Vivanco, D. \& Toppinen, A. (2014). Designers' wooden furniture ecodesign implementation in Scandinavian country-of-origin (COO) branding. Journal of Product \& Brand Management, 23(3), 180-191.

Murray, J., Elms, J. \& Curran, M. (2019). Examining empathy and responsiveness in a high-service context. International Journal of Retail \& Distribution Management, 47(12), 1364-1378.

Nadanyiova, M., Gajanova, L., Moravcikova, D. \& Oláh, J. (2019). The brand value and its impact on sales in automotive industry. LOGI - Scientific Journal on Transport and Logistics, 10(1), 41-49.

Olah, J., Virglerova, Z., Kliestikova, J., Popp, J. \& Kovacs, S. (2019a). The assessment of non-financial risk sources of SMEs in the V4 countries and Serbia. Sustainability, 11(17), 4806.

Olah, J., Kovacs, S., Virglerova, Z., Lakner, Z. \& Popp, J. (2019B). Analysis and comparison of economic and financial risk sources in SMEs of the Visegrad Group and Serbia. Sustainability, 11(7), 1853, 1-19.

Park, C.W., MacInnis, D.J., Priester, J., Eisingerich, A.B. \& Iacobucci, D. (2010). Brand attachment and brand attitude strength: Conceptual and empirical differentiation of two critical brand equity drivers. Journal of marketing, 74(6), 1-17.

See-To, E.W. \& Ho, K.K. (2014). Value co-creation and purchase intention in social network sites: The role of electronic Word-of-Mouth and trust-A theoretical analysis. Computers in Human Behavior, 31, 182-189.

Srivastava, R.K., Shervani, T.A. \& Fahey, L. (1998). Market-based assets and shareholder value: A framework for analysis. Journal of marketing, 62(1), 2-18.

Stahl, G., Björkman, I., Farndale, E., Morris, S.S., Paauwe, J., Stiles, P., ... \& Wright, P. (2012). Six principles of effective global talent management. Sloan Management Review, 53(2), 25-42.

Stokburger-Sauer, N.E. \& Teichmann, K. (2013). Is luxury just a female thing? The role of gender in luxury brand consumption. Journal of business research, 66(7), 889-896.

Sweeney, J.C. \& Soutar, G.N. (2001). Consumer perceived value: The development of a multiple item scale. Journal of retailing, 77(2), 203-220.

Zhang, Z., Ma, M., Leszczyc, P.T.P. \& Zhuang, H. (2020). The influence of coupon duration on consumers' redemption behavior and brand profitability. European Journal of Operational Research, 281(1), 114-128.

Xiong, X.Q., Guo, W.J., Fang, L., Zhang, M., Wu, Z.H., Lu, R., \& Miyakoshi, T. (2017). Current state and development trend of Chinese furniture industry. Journal of Wood Science, 63(5), 433-444. 